www.jmscr.igmpublication.org

Index Copernicus Value: 79.54

ISSN (e)-2347-176x ISSN (p) 2455-0450

crossrefDOI: https://dx.doi.org/10.18535/jmscr/v7i3.155

\title{
A Comparative Study of Serum C-Reactive Protein, Urea and Creatinine Levels in Chronic Kidney Disease Patients with Normal Subjects
}

\author{
Authors \\ Dr Nita Sahi ${ }^{1}$, Pankaj Sharma ${ }^{2}$ \\ ${ }^{1}$ Associate Professor Dept. of Biochemistry Pacific Medical College \& Hospital Udaipur (Rajasthan), India \\ ${ }^{2}$ PG Student Dept. of Biochemistry Pacific Medical College \& Hospital Udaipur (Rajasthan), India \\ Email: shubhamjain094@gmail.com, Mob.9116051017
}

\begin{abstract}
Introduction: Chronic diseases have become a major public health problem. Chronic diseases are a leading cause of morbidity and mortality in India and other low and middle-income countries. Kidney damage is defined as "pathologic abnormalities of marker of damage, including abnormalities in blood or urine tests or imaging studies."

Aims and Objective: This study aims to estimate C-reactive protein, urea, creatnine levels, which is an indicator of inflammation and prognonosis in CKD because this will help the medical staff for proper management with less morbidity and mortality.

Methods of Assay: Estimation of serum C-reactive protein, serum urea, and creatinine will be assessd by using commercially reagents and kits.

Result: CKD is more common in old age group or chance of that majority of our patients where male and in the age group of 10-60 getting CKD increases as the age of person increases. The male constituted about $60 \%$ of the total. While female patients constituted about $40 \%$ of total patients.

Conclusion: It is concluded that maximum number of chronic kidney diseases occur in the man than women. Age prone to kidney diseases is 41-50 years. CKD is directly proportional to age.
\end{abstract}

\section{Introduction}

Chronic diseases have become a major public health problem. Chronic diseases are a leading cause of morbidity and mortality in India and other low- and middle-income countries. The chronic diseases account for $60 \%$ of all deaths worldwide. Eighty percentage of chronic disease deaths worldwide occur in low and middle-income countries. ${ }^{1} \mathrm{CKD}$ is defined as kidney damage or glomerular filtration rate (GFR) $<60 \mathrm{~mol} / \mathrm{min} / 1.73$ $\mathrm{m} 2$ for 3 months or more, irrespective of cause. ${ }^{2}$ Kidney damage is defined as "pathologic abnormalities or markers of damage, including abnormalities in blood or urine tests or imaging studies." 3 CKD can be detected via simple biochemical tests including a creatinine-based estimate of the glomerular filtration rate (GFR). Serum C Reactive protein level is elevated in patients with chronic kidney disease. ${ }^{4-5}$ Urea, and creatinine concentrations of middle and late stage chronic kidney disease patients were obviously higher than those of healthy people and early stage chronic kidney disease patients. ${ }^{6,7}$

In community based studies, the chronic kidney disease prevalence has been reported between $0.16 \%$ and $0.79 \%$. The studies were designed to 
detect stage -3 chronic kidney disease or worse and the renal prevalence of chronic kidney disease is higher than the reported number. ${ }^{8,9,10}$

The end stage renal disease incidence has been reported to be 160 to 232 (PMP). The projected end stage renal disease prevalence was 785 to 870 pmp. $^{11,12,13}$ There are different renal function parameters to indicate reduced kidney function. CKD typically increases with age and therefore there is increased risk in older adults. It is found that females are less prone to the risk of CKD. ${ }^{14,15}$ The declaration of World Kidney Day to be observed annually beginning in March 2006 sends a clear message to the public, government health officials, physicians, allied health professionals, patients, and families that ' $\mathrm{CKD}$ is common, harmful, and treatable ${ }^{, 16}$ The incidence of CKD increases with age. The annual incidence in middle aged is about $1 \%$. Women have higher incidence of CKD but lower risk for kidney failure than men. African Americans have higher risk for kidney failure. ${ }^{17,18}$

So this study is designed to determine the following:-

- To estimate serum level of C-reactive protein, urea and cretnine in normal subjects.

- To estimate serum serum level of Creactive protein, urea and creatnine level in CKD.

- To compare serum level of C-reactive protein, urea and creatnine in $\mathrm{CKD}$ patients and normal subjects.

\section{Methodology}

\section{Study Place and Design}

This study will be carried out in department of Biochemistry in collaborations with department of medicine, and department of microbiology of pacific medical college and hospital, Udaipur. It is observational case control study, will include 100 subjects. Out of 100 subjects, 50 patients of chronic kidney disease and another 50 normal subjects will be age and sex matched healthy volunteers as control group. The control group will be taken for patient's attendants, staff, and student and may be from private laboratories which conduct routine serum check up of healthy persons.

\section{Investigations}

- $\quad$ Estimation of serum urea

\section{Principal}

The quantitative estimation serum urea is done by semi-analyzer using enzymatic kit

- $\quad$ Estimation of serum creatnine

\section{Principal}

The quantitative estimation serum urea is done by semi-analyzer using enzymatic kit

- $\quad$ Estimation of serum C-reactive protein

PrincipalSemi-quantitative analysis of CRP is done by Latex agglutination method.

\section{Statically Analysis}

Data will be entered on SPSS in the form of master chart. This data will be classified and analyzed as per aims and objectives. Quantitative data will be expressed in the form of Mean + SD .Infrence will be drawn with the use of appropriate test of significance.

\section{Observation}

Table-: 1

Mean \pm SD of Various Parameters of Cases \& Control Group Subjects

\begin{tabular}{|c|c|c|c|c|}
\hline \multirow[t]{2}{*}{ Parameters } & \multicolumn{2}{|c|}{ Mean + SD } & \multirow{2}{*}{ P-Value } & \multirow{2}{*}{ Significance } \\
\hline & CONTROL & CASE & & \\
\hline Urea & $32.78 \pm 4.52$ & $102.34 \pm 24.92$ & $<0.0001$ & HS \\
\hline Creatinine & $1.014 \pm 0.19$ & $10.64 \pm 2.56$ & $<0.0001$ & HS \\
\hline CRP & - & - & $>0.05$ & NS \\
\hline
\end{tabular}




\section{Fig.-1: DISTRIBUTION OF STUDY POPULATION ACCORDING TO THEIR CRP TEST RESULT}

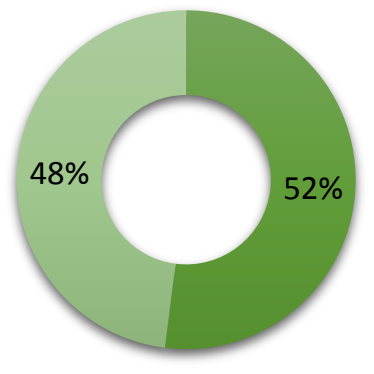

CRP +ve

CRP -ve

Table:-2 Distribution of Cases According to CRP Result

\begin{tabular}{|l|c|c|}
\hline & NO. & $(\%)$ \\
\hline CRP +ve & 26 & 52.0 \\
\hline CRP -ve & 24 & 48.0 \\
\hline
\end{tabular}

Table 3:- Distribution of Cases According to their Age

\begin{tabular}{|l|c|c|}
\hline AGE & NO. & $(\%)$ \\
\hline 10-20 YEARS & 1 & 2.0 \\
\hline $21-30$ YEARS & 4 & 8.0 \\
\hline 31-40 YEARS & 8 & 16.0 \\
\hline 41-50 YEARS & 20 & 40.0 \\
\hline 51-60 YEARS & 17 & $\mathbf{3 4 . 0}$ \\
\hline TOTAL & 50 & $\mathbf{1 0 0 . 0}$ \\
\hline
\end{tabular}

\section{Result \& Discussion}

Table 1 shows that The mean serum Urea level was found to be $32.78 \pm 4.52 \mathrm{mg} / \mathrm{dl}$ in control subjects and The mean serum urea level was found to be $102.34 \pm 24.92 \mathrm{mg} / \mathrm{dl}$ in the patients of chronic kidney disease and p-value is $<0.0001$ and highly significant .

Table 1 shows that The mean serum creatinine level was found to be $1.014 \pm 0.19$ in control subjects and The mean serum creatinine level was found to be $10.64 \pm 2.56 \mathrm{mg} / \mathrm{dl}$ in patients of chronic kidney disease and p-value is $<0.0001$ and highly significant. This increase might be due to decreased excretion of creatinine by poor functioning of kidney.

Table no.1 shows that all control subjects have CRP test negative means they do not have any kidney disease particularly or their renal function is normal. As CRP is an acute phase reactant, it is a marker of inflammation; its negativity shows absence of inflammation in control High CRP levels provide prognostic information in patients with CKD

Table No.2 and Fig.1 shows in patients with chronic kidney disease, 26 patients (52\%) s are showing increased level of CRP but $48 \%$ patients show negative CRP level which means low level and this value does not correlates with previous studies done in past and establish the need of further study of CRP level in CKD patients. The question as to whether inflammation contributes to progressive renal dysfunction in CKD patients needs further investigation.

Table 3 show that the maximum number of cases $20(40 \%)$ were in age group of 41-50 years, followed by $17(34 \%)$ cases in 51-60 and minimum number $(02 \%)$ of cases was in age group 10-20 followed by (08 \%) cases in 21-30 age group. Number of CKD patients is less in younger age group. 


\section{Conclusion}

From above it is concluded that maximum number of chronic kidney diseases occur in the men than women. Age prone to kidney diseases is 41to 50 years. CKD is directly proportional to age. Men are more vulnerable because of their smoking; drinking habits. Other etiological factors include genetic, atherosclerosis, diabetes, obesity etc. Non- malignant hypertension is also an initiator of kidney diseases. Early diagnosis and precautions should be taken to minimize the ill effects of CKD.

\section{Bibliography}

1. World Health Organization: Preventing chronic disease: A vital investment. Geneva, WHO. 2005

2. Levey AS1, Eckardt KU, Tsukamoto Y, "kidney definition and classifications of chronic kidney disease : a position statement from kidney disease: Improving Global Outcomes (KDIGO)". 2005; 67(6):2089-2100.

3. CKD registry of India: Indian Society of Nephrology. [Online] Available from http://www.ckdri.org [Accessed September 2012]

4. Garg AX, Blake PG, Clark WF et al. Association between renal insufficiency and malnutrition in adults: result from the NHANES III. Kidney Int 2001; 60:18671874

5. Shlipak MG, Fried LF, Crump C et al. Elevations of inflammatory and procoagulant biomarkers in elderly persons with renal insufficiency. Circulation 2003; 107: 87-92

6. Xia Y, Zhong Nan, Da Xue Xue Bao Yi, Xue Ban. "Clinical significance of urea, creatinineand uric acid levels in patients with chronic kidney disease ".

7. Grassman A, Gioberge S, Moeller S " End Stage Renal Disease patients in 2004 global overview of patients numbers, treatment modalities and associated trends". 2005; 20(12):2587-2593.

8. Agarwal SK, Dash SC, Irshad M "Prevalence of chronic renal failure in adults in Delhi, India". 2005; 20(8):16381642.

9. Mani MK. "Prevention of chronic renal failure at the community level". Kidney Int Suppl. 2003; 63(83):S86-89.

10. Mani MK. "Experience with a program for prevention of chronic renal failure in India". Kidney Int Suppl. 2005; 67(94):S75-81.

11. Agarwal SK, Dash SC, Irshad M "Prevalence of chronic renal failure in adults in Delhi, India". 2005; 20(8):16381642.

12. Modi GK, Jha V. "The incidence of end stage renal disease in India: A population based study" Kidney Int. 2006; 70(12):2131-2131.

13. Mani MK. Nephrologist sans frontiers:" Preventing CKD on assorting".Kidney Int. 2006; 70(5):821-823.

14. Defilippic, Wasserman S, Rosanio S, Tiblier E, Sperger H, Tocchi M, Christenson R, Uretsky B, Smiley M, Gold J, Muniz H, Badalamenti J, Herzog C, Henrich W. "Cardiactroponin T and Creactive protein for pridicting prognosis, coronary atherosclerosis, and cardio mayopathy in patients undergoing long term haemodylasis". Jama 2003; 290:353359

15. Xia Y, Zhong NAN, Da XUE XUE Dao Yi, Xue Ban. "Clinical significance of urea, creatnine and uric acid level in patients with chronic kidney disease". 2012; 37:11:1672-7347.

16. Levey AS, Andreoli SP, DuBose T et al. Chronic kidney disease: common, harmful and treatable -World Kidney Day 2007. Am J Kidney Dis 2007; 49: 175-179.

17. Bash LD, Coresh J, Kottgen A, Parekh RS, Fulop T, Wang Y, Astor BC: Defining 
incident chronic kidney disease in the research setting: The ARIC Study. American journal of epidemiology 2009, 170(4):414-424.

18. Grams ME, Chow EK, Segev DL, Coresh $\mathrm{J}$ : Lifetime incidence of CKD stages 3-5 in the United States. American journal of kidney diseases : the official journal of the National Kidney Foundation 2013, 62(2):245-252. 